\title{
What Determines the Incidence and Size of Remittances: Evidence for Kosovo
}

\section{Avdullah Hoti}

University of Prishtina, Faculty of Economy, Kosova avdullah.hoti@gmail.com
CroEconSur

Vol. 17

No. 2

December 2015

pp. $83-112$

Received: September 10, 2015 Accepted: December 22, 2015

Research Article

doi:10.15179/ces.17.2.3

\section{Abstract}

Kosovo ranks highly both with regard to the rate of emigration of the labor force and the level of remittances to GDP. Given poor employment prospects in Kosovo, from an individual point of view emigration might be a strategy of escaping unemployment and contributing toward household incomes. In this paper, we investigate the determinants of the incidence and size of remittances among Kosovo's emigrants. We provide unique evidence that helps to better estimate aggregate spending and remittances in Kosovo. This is the first systematic study of these issues in this post-socialist and post-conflict economy.

Keywords: remittances, brain drain, labor force, Kosovo

JEL classification: F22, J01, J60, J61 


\section{Introduction'}

From an individual point of view, emigration is an income maximizing strategy, while in macroeconomic terms emigration reduces the size of the domestic labor force and changes its skills composition, affects aggregate spending due to remittances and produces other second and third round effects. The political crisis in Kosovo following the dismantling of the socialist Yugoslavia resulted in 145,000 workers being laid-off at once, which was unseen elsewhere in transition economies. This, coupled with the lack of jobs and the political unrest, contributed to large-scale emigration. In spite of the economic upturn brought by the economic reconstruction after 1999 and large inflows of foreign aid, unemployment remains high due to the large number of new entrants, coupled with low job creation in the private sector. Therefore, from an individual point of view, emigration may be seen as a strategy of escaping unemployment and contributing toward household incomes.

In this paper, we investigate how the personal, household and other contextual characteristics shape the emigrant's decision to remit to his/her household in Kosovo. The analysis is based on the Riinvest Household and Labour Force Survey (HLFS) data and other existing data and estimates on emigration and remittances in Kosovo. The data from the Riinvest HLFS with regard to emigration and remittances is far from perfect, for reasons that we discuss later, but this is the first analysis of emigration and remittances in Kosovo. We first present evidence on migration and remittances along with their potential brain drain and brain gain consequences and the effect on the local economy (Section 2). In Section 3, we provide estimates of emigrants from Kosovo and their remittances. Using the Riinvest HLFS data, we examine the profile of emigrants and the brain drain issue. In Section 4, we review the theory of migrants' remittances. In Section 5, we provide our estimates on determinants of the incidence and size of remittances. In Section 6, we conclude.

1 The author would like to thank Professor Nick Adnett and Jean Mangan (Staffordshire University, United Kingdom) for very useful comments at an earlier draft of this paper. Special thanks go to Riinvest Institute for providing the data for my research. 


\section{Migration and Remittances: The Empirical Evidence}

The World Bank (2006) estimates that in 2002 international migrants represented 3 percent of the destination countries' population worldwide, while for the developed countries this was 8 percent. In the European Transition Countries (ETCs), prior to 1990, both international and internal migration was very limited (Leon-Ledesma and Piracha, 2004; Mansoor and Quillin, 2007). With the collapse of the socialist regime, migration intensity increased and included both permanent and temporary migration mostly toward the EU-15 (Mansoor and Quillin, 2007). A number of ETCs experienced mass migration waves (e.g., Albania), while in some others migration was unexpectedly moderate (most of the Central European countries) given their proximity to the EU and the removal of many legal barriers to migration.

The unemployment rate reached double digits in many ETCs and stayed high throughout the 1990s. However, the efficacy of migration in reducing national and regional unemployment differentials was generally low and migration flows declined through the 1990s, even though inter-regional disparities during this decade were rising (Fidrmuc, 2004). Some of these countries became net immigration areas by 2002-2003 (Salt, 2005). Further migration waves towards the EU-15 were witnessed following the EU accession of eight transition countries on May 1, 2004. Bauer and Zimmermann (1999) projected that around a quarter of million people from these eight ETCs would move to the EU-15 annually following their accession (that is, 0.05 percent of the population in the EU). The evidence after 2004 revealed that this number was generally overestimated, as many countries of the EU-15 instituted a transition period before allowing free movement of people (with the exception of the UK, Denmark and Ireland) (Salt, 2005).

For an origin country, emigration of its labor force has important implications. Emigration changes the size of the labor force. It may also change the skill 
composition of the labor force, because more educated individuals tend to migrate more. Emigration through remittances affects aggregate spending and investment in the local economy, the labor market behavior of non-migrant household members and produces other second and third round effects in the economy. There is a further effect of emigration on the economy through return migration, though we do not explore this aspect of emigration.

\section{Brain Drain and Brain Gain Consequences of Migration}

When a country experiences the emigration of highly skilled workers, then it faces a 'brain drain'. Adams (2003), analyzing 24 labor exporting countries, finds that emigrants disproportionately represent the elite of the population, though in most countries it does not involve more than 10 percent of population with higher education. Docquier, Lohest and Marfouk (2005), investigating brain drain in Latin America and the Caribbean, Asia and Africa, find that some countries suffer from high emigration rates in general, while others experience a positive selection of emigrants (i.e., emigrants are more educated than non-migrants). From the limited evidence found in transition economies, Gedeshi (2006) reports that during 1991-2000, each year 8-10 percent of lecturers and research workers at the universities and research institutions in Albania emigrated. This trend decreased after 2000 and in 2005 it was about 2 percent.

Conventional wisdom has seen the emigration of skilled workers as damaging the country of emigration. It affects the income level and long-run economic growth and makes the country less attractive to foreign direct investment. Emigration of highly skilled workers increases the fiscal burden of those left behind, because the former are typically net contributors to the government budget. Skilled and unskilled workers are frequently complements in the production process and emigration of skilled workers may decrease the productivity of the remaining unskilled labor (Docquier and Rapoport, 2004). 
Recently, a new 'brain drain - brain gain' literature has emerged (Stark, Helmenstein and Prskawetz, 1998; Vidal, 1998; Stark, 2004), contradicting this view on the ground that emigration of skilled workers contributes to more investment in human capital by the remaining non-migrant workers with a net brain gain. It argues that an economy open to emigration provides workers with more opportunities, relative to when the economy is closed, that increase the prospective returns to human capital. Schiff (2005) contends that this new 'brain drain - brain gain' literature does not consider various negative effects of brain drain on human capital, welfare and growth.

\section{Remittances and Their Economic Impacts}

We define remittances as the money and goods that emigrants send to their households located in the country of origin. However, the effects of remittances on the recipient economy depend upon whether they are used for consumption or investment purposes. When we consider an economy such as Kosovo, there is the question of whether the flow of money from emigrants is classed as 'remittances' or 'investment'. For the purpose of this study, when emigrants invest in a business in the origin country, this would be classed as an investment flow and would not be included in the calculation of remittances to the origin country. However, money and goods that emigrants send to family members in the origin country is considered in the total flow of remittances, even if these are then used by household members for investment purposes.

For many transition and developing economies, remittances are the second largest source of external finance after foreign direct investments (Ratha, 2004; Schiopu and Siegfried, 2006). Worldwide, the World Bank (2006) estimates that international remittances rose from US\$87 billion in 2000 to US\$167 billion in 2005, with the actual size including unrecorded transfers likely to be higher. For selected ETCs in 1999, León-Ledesma and Piracha (2004) estimate remittances to be around US\$7 billion. Based on the World Bank Indicators database, in 2004 
international remittances received by 24 transition economies were estimated at US\$18.6 billion (Table 1). Similar estimates for transition economies are provided by Mansoor and Quillin (2007). More importantly, these remittance flows are found to be less volatile than foreign direct investments or exports (Schrooten, 2005).

The macroeconomic impact of remittances depends partly on whether they are used for consumption or investment purposes. If they are used for investment purposes, then they are expected to shift the 'production frontier' of the receiving countries. Nevertheless, as Adams (2005) argues, even if remittances are used for consumption purposes, they may free other sources of finance that can be used for investment purposes.

For 11 ETCs in the period 1990-1999, Leon-Ledesma and Piracha (2004) find a positive effect of remittances on aggregate output through financing investment and entrepreneurial activities. Catrinescu et al. (2006) contend that remittances have also produced negative effects through appreciating the real exchange rate that affects the tradable sector. Schrooten (2005) argues that since remittances enable the economy to spend more than it produces, then they might encourage the Dutch disease and more migration. This increases the dependency of the economy on these financial flows.

Remittances are found to affect human capital formation in the receiving countries through easing the liquidity constraints on educational spending by households. Hanson and Woodruff (2003) find for Mexico that children in households with a migrant member complete significantly more years of schooling. Adams (2005) finds for Guatemala that, at the margin, households receiving remittances spend more on education and that most of these increments to expenditure go into postcompulsory education where enrolment is more prone to financial constraints. 
Table 1: International Remittances in Transition Economies in Millions of US\$ (2000-2004)

\begin{tabular}{|c|c|c|c|c|c|c|}
\hline \multirow{2}{*}{ Countries * } & \multicolumn{5}{|c|}{ Remittances in millions of US\$ } & \multirow{2}{*}{$\begin{array}{c}\text { Remittances/ } \\
\text { GDP** } \\
\text { in } 2004\end{array}$} \\
\hline & 2000 & 2001 & 2002 & 2003 & 2004 & \\
\hline & {$[1]$} & {$[2]$} & [3] & {$[4]$} & [5] & {$[6]$} \\
\hline Moldova & 179 & 243 & 323 & 486 & 703 & 0.271 \\
\hline Bosnia \& Herzegovina & 1,595 & 1,521 & 1,526 & 1,745 & 1,824 & 0.214 \\
\hline Serbia \& Montenegro & 1,132 & 1,698 & 2,089 & 2,661 & 4,129 & 0.172 \\
\hline Tajikistan & n.a. & n.a. & 79 & 146 & 252 & 0.122 \\
\hline Albania & 598 & 699 & 734 & 889 & 1,160 & 0.117 \\
\hline Armenia & 87 & 94 & 131 & 168 & 336 & 0.109 \\
\hline Kyrgyz Republic & 9 & 11 & 37 & 78 & 189 & 0.086 \\
\hline Georgia & 274 & 181 & 230 & 239 & 303 & 0.058 \\
\hline Macedonia & 81 & 73 & 106 & 174 & 213 & 0.040 \\
\hline Croatia & 641 & 747 & 885 & 1,085 & 1,222 & 0.036 \\
\hline Azerbaijan & 57 & 104 & 182 & 171 & 228 & 0.027 \\
\hline Latvia & 72 & 112 & 138 & 173 & 230 & 0.017 \\
\hline Lithuania & 50 & 79 & 109 & 115 & 325 & 0.015 \\
\hline Estonia & 3 & 9 & 17 & 49 & 164 & 0.015 \\
\hline Poland & 1,726 & 1,995 & 1,989 & 2,655 & 2,710 & 0.011 \\
\hline Belarus & 139 & 149 & 140 & 222 & 244 & 0.011 \\
\hline Slovakia & 18 & 24 & 24 & 425 & 425 & 0.010 \\
\hline Ukraine & 33 & 141 & 209 & 330 & 411 & 0.006 \\
\hline Russia & 1,275 & 1,403 & 1,359 & 1,453 & 2,668 & 0.005 \\
\hline Bulgaria & 58 & 71 & 72 & 67 & 103 & 0.004 \\
\hline Czech Republic & 297 & 257 & 334 & 498 & 454 & 0.004 \\
\hline Kazakhstan & 122 & 171 & 205 & 148 & 167 & 0.004 \\
\hline Hungary & 281 & 296 & 279 & 295 & 307 & 0.003 \\
\hline Romania & 96 & 116 & 143 & 124 & 132 & 0.002 \\
\hline Total & 8,823 & 10,194 & 11,340 & 14,396 & 18,899 & - \\
\hline
\end{tabular}

Source: World Development Indicators database, available from http://devdata.worldbank.org/data-query/, date accessed 20 June 2006.* The order of countries is by the ratio of remittances/GDP presented in column 6. ${ }^{* *}$ Own calculations using data from the World Development Indicators database.

Remittances affect the labor supply of non-migrant household members through two different channels. First, based on the neoclassical model of labor-leisure choice, remittances shift the budget line upwards, increase the reservation wage and consequently decrease the labor supply of non-migrant household members (assuming that leisure is a normal good). Evidence for this 
is provided by Funkhouser (1992) for Nicaragua, Rodriguez and Tiongson (2001) for the Philippines, Konica and Filer (2005) for Albania and AmuedoDorantes and Pozo (2006) for Mexico. Second, in line with macroeconomic evidence, remittances increase the propensity of some non-migrant household members (males in particular) to engage in self-employment through financing entrepreneurial projects. This may be particularly important for transition and developing economies where the credit market is underdeveloped. Supportive evidence for this is provided by Funkhouser (1992), Konica and Filer (2005) and Amuedo-Dorantes and Pozo (2006).

\section{Emigrants from Kosovo, Their Remittances and the Brain Drain Issue}

\section{Estimates on Emigrants and Their Remittances}

As a consequence of its young population, persistent high unemployment and political unrest, especially during the 1980s and the 1990s, Kosovo has experienced both temporary and permanent mass emigration. During the socialist era in the late 1960s, many workers from Yugoslavia emigrated to Western Europe (West Germany in particular), which at that time experienced a shortage of labor (Zimmermann, 1995). Moalla-Fetini et al. (2005) report that in 1973 this number reached 1.1 million (equivalent to 12 percent of Yugoslavia's labor force). Emigration from Kosovo broadly resembled that of Yugoslavia. In 1981, there were some 27 thousand emigrants from Kosovo, while between 1981 and 1987 another 50 thousand people emigrated. Further large migration waves were witnessed following the break-up of the former socialist Yugoslavia (after 1989) and the poor economic prospects that prevailed during the 1990s. There are no official data on emigrants either during the 1990s or after the war of 1999. Bush (2004) uses data from the Demographic and Health Survey (DHS) conducted by the Statistical Office of Kosova (SOK) in 2003 and data from the destination countries to estimate the number of emigrants in the range of 300 to 
500 thousand. Moalla-Fetini et al. (2005) estimate this number at approximately 470 thousand (that is, around 20 percent of the total population estimated at 2.4 million). Among transition economies, only Albania has had such a high emigration rate.

Regarding remittances, Bush (2004) estimates them using DHS data at $€ 174$ million annually. Moalla-Fetini et al. (2005) argue that this is an underestimation because of the following: (i) the household survey fails to capture infrequent remittances; (ii) households may be hesitant to report the full amount of remittances out of fear of drawing attention to their own finances; and (iii) households may be reluctant to report remittances from household members working abroad illegally. They estimate annual remittances at $€ 241$ million. This is 13.4 percent of the estimated 2003 GDP ( $€ 1,797$ million) and approximately 25 percent of imports in that year (€968.5 million).

Our estimates from the Riinvest HLFS conducted in December 2002 indicate that 254 (20 percent) out of 1,252 households in the sample receive remittances (defined as 'money received from household members working abroad'). The average amount per month for those households that receive remittances is $€ 302$. If distributed across all households, then on average each household in the sample receives remittances of $€ 61$ per month. As such, remittances constitute 14 percent of the monthly household income of $€ 428$. They are the second largest income source after income from salaries. Assuming the number of households in Kosovo is 320,000 , then annual remittances amount to $€ 234$ million, which is close to the estimates by Moalla-Fetini et al. (2005). Therefore, remittances are as high as 13.4 percent of GDP, ranking Kosovo among the top five in terms of the ratio of remittances to GDP in transition countries (see Table 1). However, we note the fact that Kosovo's migrations generate both remittances and investments, with an unclear distinction between these two types of monetary flows entering the economy of Kosovo. There is evidence that emigrants often invest in real estate in Kosovo through buying a house or an apartment. However, money 'invested' in non-productive real estate might be classed as remittance since this money 
often generates no surplus for the person sending the money. Therefore, buying real estate in Kosovo is often more like a remittance flow than an investment.

\section{Characteristics of Emigrants and the Brain Drain Issue}

To examine the characteristics of emigrants and the extent of brain drain in Kosovo, we use the Riinvest HLFS data. The question asked to the household head (or the person replacing him or speaking on his behalf) in the interview was to provide details of the household members abroad.

Table 2: The Characteristic of the Sample of Emigrants from Kosovo Based on the Riinvest HLFS (2002) (all data is in proportions unless otherwise stated)

\begin{tabular}{|c|c|c|c|c|c|}
\hline & $\begin{array}{c}\text { Emigrants } \\
\left(\mu_{1}\right)\end{array}$ & $\begin{array}{c}\text { Non- } \\
\text { migrants } \\
\left(\mu_{2}\right)\end{array}$ & $\begin{array}{c}\text { Total } \\
\text { population }\end{array}$ & $\underbrace{\text { Emigration }}_{\text {rate }}$ & $\begin{array}{c}\text { Test } \\
\text { results: }{ }^{*} \\
\mathrm{H}_{0}: \mu_{1}=\mu_{2}\end{array}$ \\
\hline & {$[1]$} & {$[2]$} & {$[3]$} & {$[4]$} & [5] \\
\hline Total in the sample & 576 & 7,976 & 8,552 & 0.067 & - \\
\hline \multicolumn{6}{|l|}{ Gender } \\
\hline Males & 0.663 & 0.492 & 0.503 & 0.089 & Rejected \\
\hline Females & 0.337 & 0.508 & 0.497 & 0.046 & - \\
\hline \multicolumn{6}{|l|}{ Residence in Kosovo } \\
\hline Urban residents & 0.35 & 0.446 & 0.44 & 0.054 & Rejected \\
\hline Rural residents & 0.65 & 0.554 & 0.56 & 0.078 & - \\
\hline Age (average years) & 26.37 & 27.39 & 27.32 & - & Not rejected \\
\hline \multicolumn{6}{|l|}{ Age group } \\
\hline $0-15$ & 0.22 & 0.33 & 0.32 & 0.05 & Rejected \\
\hline $16-24$ & 0.18 & 0.19 & 0.19 & 0.06 & Not rejected \\
\hline $25-34$ & 0.37 & 0.15 & 0.17 & 0.15 & Rejected \\
\hline $35-44$ & 0.15 & 0.12 & 0.12 & 0.08 & $\begin{array}{c}\text { Not } \\
\text { rejected }\end{array}$ \\
\hline $45-54$ & 0.05 & 0.09 & 0.09 & 0.04 & Rejected \\
\hline $55-64$ & 0.03 & 0.06 & 0.06 & 0.03 & Rejected \\
\hline $65+$ & 0.01 & 0.05 & 0.05 & 0.01 & Rejected \\
\hline $0-15$ & 0.22 & 0.33 & 0.32 & 0.05 & - \\
\hline $16-64$ & 0.77 & 0.62 & 0.63 & 0.08 & Rejected \\
\hline Over 64 & 0.01 & 0.05 & 0.05 & 0.01 & - \\
\hline
\end{tabular}


Education level (age 25+)

\begin{tabular}{l|c|c|c|c|c} 
Less than upper-secondary & 0.277 & 0.489 & 0.471 & 0.049 & Rejected \\
\hdashline Upper-secondary education & 0.612 & 0.386 & 0.405 & 0.126 & Rejected \\
\hdashline Higher education & 0.111 & 0.125 & 0.124 & 0.074 & Not rejected \\
\hdashline $\begin{array}{l}\text { Average years of education } \\
\text { (age 25+) }\end{array}$ & 11.08 & 9.92 & 10.02 & - & Rejected
\end{tabular}

Occupation for those with higher education

\begin{tabular}{|c|c|c|c|c|c|}
\hline Teacher & 0.07 & 0.18 & 0.17 & 0.03 & - \\
\hline Economist & 0.13 & 0.17 & 0.16 & 0.06 & - \\
\hline Lawyer & 0.02 & 0.06 & 0.05 & 0.03 & - \\
\hline Engineer & 0.24 & 0.12 & 0.13 & 0.13 & - \\
\hline Doctor & 0.11 & 0.06 & 0.06 & 0.13 & - \\
\hline Linguist & 0.07 & 0.05 & 0.05 & 0.09 & - \\
\hline Other & 0.37 & 0.36 & 0.36 & 0.07 & - \\
\hline In employment (age 16-64) & 0.61 & 0.30 & - & - & - \\
\hline $\begin{array}{l}\text { Earnings in } € / \text { month for } \\
\text { those employed }\end{array}$ & 1,332 & 215 & - & - & - \\
\hline
\end{tabular}

Country of emigration

\begin{tabular}{|c|c|c|c|c|c|}
\hline Germany & 0.43 & - & - & - & - \\
\hline Switzerland & 0.22 & - & - & - & - \\
\hline Other EU countries & 0.06 & - & - & - & - \\
\hline USA and Canada & 0.04 & - & - & - & - \\
\hline $\begin{array}{l}\text { Other former Yugoslav } \\
\text { countries }\end{array}$ & 0.04 & - & - & - & - \\
\hline All other countries & 0.22 & - & - & - & - \\
\hline
\end{tabular}

Year of emigration for the first time

\begin{tabular}{|c|c|c|c|c|c|}
\hline $1970-1979$ & 0.03 & - & - & - & - \\
\hline 1980-1989 & 0.12 & - & - & - & - \\
\hline 1990-1999 & 0.58 & - & - & - & - \\
\hline $2000-2002$ & 0.10 & - & - & - & - \\
\hline No answer & 0.18 & - & - & - & - \\
\hline \multicolumn{6}{|l|}{ Remit (age 16+) } \\
\hline Yes & 0.49 & - & - & - & - \\
\hline No & 0.51 & - & - & - & - \\
\hline $\begin{array}{l}\text { Average amount remitted in } \\
€ / \text { month for those emigrants } \\
\text { who remit (age } 16+)\end{array}$ & 347 & - & - & - & - \\
\hline $\begin{array}{l}\text { Average amount remitted in } \\
€ / \text { month for all emigrants } \\
\text { (age } 16+)\end{array}$ & 170 & - & - & - & - \\
\hline
\end{tabular}

Source of data: Riinvest HLFS of December 2002.

${ }^{*}$ Indicates whether Ho: $\mu_{1}=\mu_{2}$ can be rejected at 5 percent level of significance. ${ }^{* *} \mathrm{H}_{0}$ can be rejected at 10 percent. 
Some 20 percent of the 1,252 households in the sample responded that they had at least one member abroad. In the Riinvest HLFS in 95 percent of cases it was the head of the household that was interviewed, providing data for all household members, which suggests that the responses were fairly accurate. Out of 8,552 individuals in the sample, some 576 are emigrants (6.7 percent). Note that when an entire household had moved abroad then it would not be included in the sample. This is one reason why we observe only 6.7 percent of the population as emigrants compared to the 20 percent estimated by Moalla-Fetini et al. (2005), which is a main deficiency of the Riinvest HLFS data with regard to emigration and remittances.

The characteristics of these emigrants are presented in column 1 of Table 2 , while in columns 2 and 3 we show the data for non-migrants and the total population, respectively. These data indicate that emigrants are disproportionately of working age, males, from rural areas and with upper-secondary education. As shown in column 5, almost all of these differences between migrants and non-migrants are statistically significant.

As expected, about 61 percent of emigrants aged 16-64 are working compared to 30 percent of non-emigrants. The average monthly wage for emigrants is six times higher than for non-migrants (€1,332 compared to €215). More than twothirds of emigrants are residing in Germany and Switzerland. As we discussed above, the first emigrants during the 1970s went to these countries, suggesting that migration networks contributed to the concentration of emigrants in these two countries. Some 49 percent of emigrants aged 16 and over remit, and amongst these the average amount remitted is $€ 347$ per month. Regarding the brain drain, we find that 7.4 percent of our sample aged 25 and over with higher education are emigrants. This is comparable to findings in other countries, but note that our data does not include permanent emigrants and therefore provides only the lower bound of the brain drain in Kosovo. 
Table 3: Estimates of the Brain Drain in Kosovo

\begin{tabular}{l|c|c|c|c} 
& $\begin{array}{c}\text { Proportion } \\
\text { in the total } \\
\text { population }\end{array}$ & Population & $\begin{array}{c}\text { Emigration } \\
\text { rate* }\end{array}$ & $\begin{array}{c}\text { Number of } \\
\text { emigrants }\end{array}$ \\
\cline { 2 - 4 } & {$[1]$} & {$[2]$} & {$[3]$} & {$[4]=[2] \mathrm{x}[3]$} \\
\hline Total population & 1.000 & $2,400,000^{* *}$ & 0.067 & 160,800 \\
\hline $\begin{array}{l}\text { Population of age 25+ } \\
\text { Education level of the population aged 25+ }\end{array}$ & 0.490 & $1,176,000^{* * *}$ & 0.083 & 97,608 \\
\hline $\begin{array}{l}\text { Less than upper-secondary } \\
\text { education }\end{array}$ & 0.471 & $553,896^{* * *}$ & 0.049 & 27,141 \\
\hline Upper-secondary education & 0.405 & $476,280^{* * *}$ & 0.126 & 60,011 \\
\hline Higher education & 0.124 & $145,824^{* * *}$ & 0.074 & 10,791 \\
\hline
\end{tabular}

Source of data: ${ }^{*}$ Riinvest HLFS of December 2002. ${ }^{* *}$ Estimated by Moalla-Fetini et al. (2005) including emigrants. *** Own calculations by multiplying the respective proportion in the population from column 1 with the total number of population.

In Table 3, we quantify the brain drain assuming a population of 2.4 million. Based on the distribution of population by age from the Riinvest HLFS, the population of age 25 and over is estimated at 1.176 million. Following this approach, in column 4 we find that there are around 11 thousand emigrants with higher education, which is equivalent to four years output from higher education in Kosovo. Note also that the emigration rate of individuals with upper-secondary education is almost twice the overall emigration rate.

\section{The Theory of Migrants' Remittances and Our Estimation Strategy}

\section{The Theory of Migrants' Remittances and Our Estimation Strategy}

The motivations for migrants' remittances are thought to be similar to motivations for other intra-household transfers. First, migrants may remit induced by altruistic behavior, where remittances increase with migrants' incomes and the degree of altruism and decrease with household incomes. Second, remittances can also reflect migrants' desires to diversify their portfolios (Bouhga-Hagbe, 2006). Third, remittances may be viewed as repayments of loans used to finance 
migration costs and/or migrants' human capital. Finally, migrants may remit to ensure that in the future they will be given rights towards their household's wealth.

To estimate emigrants' remittances in the case of Kosovo we follow the model provided by Funkhouser (1995), where an emigrant's utility function includes the utility of the household left behind:

$U\left(U_{m}, U_{h}\right)=U_{m}\left(C_{m}\right)+V\left\{U_{h}\left(C_{h}\right), Z\right\}$

where $U_{m}$ is the emigrant's own utility and $U_{h}$ is the household utility in the source country, and each are dependent on consumption $C_{m}$ and $C_{h}$, respectively. The importance of the utility of the household left behind in the migrant's own utility $U$ depends on the relationship of the migrant to the household captured by the vector $Z$. Funkhouser derives the orthodox neoclassical proposition, that at the margin the increase in the utility from an increase in household incomes in the origin country of migration due to remittances exactly offsets the decrease in utility from lower own consumption resulting from that transfer. Some of the testable predictions are: (i) lower household incomes are associated with higher remittances, ceteris paribus; (ii) the stronger the relationship of the emigrant to the household, the higher the level of remittances; (iii) the time profile of remittance behavior depends on the relative size of the discount factors and the earnings profile of the emigrant; (iv) emigrants with higher earnings will remit more; and (v) the existence of multiple emigrants from the same household reduces remittances from any given emigrant. In the empirical estimation for Kosovo we test some of these predictions.

Since we aim to investigate (i) the probability that an emigrant remits and (ii) determinants of the size of remittances, we estimate two models. In the former case, the dependent variable is of dichotomous nature, taking values of 1 if the emigrant remits and 0 if not, such that: 
$y_{i}=\left\{\begin{array}{ll}1 & \text { if } y_{i}>0 \\ 0 & \text { if } y_{i}=0\end{array}\right\}$

where $y_{i}$ denotes the observed amount of remittances sent home (in €/month) by the emigrant $i$. We estimate a probit model:

$\operatorname{Pr}\left(y_{i}>0 \mid x_{i}\right)=\Phi\left(x_{i} \beta\right)$

where $x_{i}$ is a vector of explanatory variables expected to affect $y_{i}$.

Regarding the determinants of the size of remittances, we employ the Tobit model (Tobin, 1958; usually referred to as the Tobit I model) for the reasons that we explain below. We observe that 49 percent of emigrants aged 16 and over remit (i.e., $y_{i}>0$ ). Since the rest do not (i.e., $y_{i}=0$, corner solution), the dependent variable is a continuous variable, but truncated at zero. ${ }^{2}$ If OLS is fitted to the sample with $y>0$ (i.e., in our case to the sample of emigrants who remit) then the estimated coefficients will be biased and inconsistent (Wooldridge, 2002). The Tobit model handles the situations when $\mathrm{y}$ is characterised by the corner solution (Wooldridge, 2002, pp. 518-19; Greene, 2003, p.778) and is specified as follows:

$y_{i}^{*}=x_{i} \beta+u_{i}$

$y_{i}=\left\{\begin{array}{cc}0 & \text { if } y_{i}^{*}=0 \\ y_{i}^{*} & \text { if } y_{i}^{*}>0\end{array}\right\}$

where $y_{i}^{*}$ is the latent variable and $y_{i}$ is its observed counterpart, $x_{i}$ is a vector of explanatory variables expected to affect $y_{i}^{*}, \beta$ is the vector of parameters to

2 Although theoretically remittances may be negative (i.e., when a household in Kosovo sends money to its emigrant member abroad), this did not occur in our sample. 
be estimated and $u_{i}$ is assumed to be NID $(0, \sigma 2)$ and independent of $x_{i}$. The expected value of $y$ is expressed as:

$E\left(y_{i} \mid x_{i}\right)=\operatorname{Pr}\left(y_{i}=0 \mid x_{i}\right) \cdot 0+\operatorname{Pr}\left(y_{i}>0 \mid x_{i}\right) E\left(y_{i} \mid y_{i}>0, x_{i}\right)=\operatorname{Pr}\left(y_{i}>0 \mid x_{i}\right) E\left(y_{i} \mid y_{i}>0, x_{i}\right)$

The Tobit model involves estimating $\operatorname{Pr}\left(y_{i}>0 \mid x_{i}\right)=\operatorname{Pr}\left(u_{i}>-x_{i} \beta \mid x_{i}\right)$ and $E\left(y_{i} \mid y_{i}>0, x_{i}\right)=x_{i} \beta+E\left(u_{i} \mid u_{i}>-x_{i} \beta\right)$.

In the framework of this model, the direction (i.e. the sign) of the effect of explanatory variables $x_{i}$ on $y_{i}$ is the same with regard to $\operatorname{Pr}\left(y_{i}>0 \mid x_{i}\right)$ and $E\left(y_{i} \mid y_{i}>0, x_{i}\right.$, $)$. The marginal effect can be split into two parts. First, if $y_{i}=0$, as $x_{i} \beta$ increases, then the probability that $y_{i}>0$ increases. Second, if $y_{i}>0$ as $x_{i} \beta$ increases, then the mean response of $y_{i}$ increases. It follows that:

$$
\frac{\partial \mathrm{E}\left(y_{i}\right)}{\partial x_{i}}=\frac{\partial \operatorname{Pr}\left(y_{i}>0\right)}{\partial x_{i}} \mathrm{E}\left(y_{i} \mid y_{i}>0\right)+\operatorname{Pr}\left(y_{i}>0\right) \frac{\partial \mathrm{E}\left(y_{i} \mid y_{i}>0\right)}{\partial x_{i}}
$$

More specifically, the Tobit model provides for two marginal effects on the observed $y$ :

$\partial E(y) / \partial x_{i}=F(z) \beta_{i}$

$\partial E(y \mid y>0) / \partial x_{i}=\beta_{i}\left(1-(z) \lambda-\lambda^{2}\right)$

where $\lambda=f(z) / F(z), z=\beta x i / \sigma, \sigma$ is the standard error term and $f$ and $F$ are the probability and the cumulative density function, respectively. They are referred to as the unconditional and condition marginal effects, respectively. Our data is left-censored from below and we apply the left-censored Tobit model. 


\section{The Choice of the Explanatory Variables and Descriptive Statistics}

The choice of explanatory variables is guided by the theory of migrants' remittances discussed above and they are identified in Table 4. Education and employment status influence an emigrant's earnings and are expected to have a positive effect on the probability of remitting and on the amount remitted. The marital status is expected to have a negative impact on the probability of remitting due to the need to meet the family obligations. The household size is expected to have a negative effect since it increases the likelihood that other household members who may also remit are abroad. The probability of remitting and the amount remitted are expected to decrease with an increase in household income in Kosovo. Remittances may increase with the number of years of emigration since the earning power of the emigrant increases (perhaps due to accumulated experience). Years of emigration squared is expected to be negative since the emigrant's ties with the household in Kosovo may weaken through time. We also control for any effect due to the urban/rural residence of the household left behind. The sample in both the probit and the Tobit model consists of emigrants aged 16 and over.

The characteristics of the sample are shown in Table A1 in Appendix. As expected, employment status seems to be highly correlated with the incidence of remitting (namely, 99 percent of emigrants who remit are employed, compared to 22 percent of emigrants that do not remit). Those who remit tend to be male, older and to have on average more years of emigration than those who do not remit.

As it may be expected, data on the amount remitted by emigrants might be under-reported due to households fearing that they will draw attention to their own finances. This inaccuracy is expected to be more in terms of their amount rather than in reporting remittances at all. In the estimations, those emigrants for whom the amount remitted is missing are treated as not remitting. This approach is also supported by our test results in Table A2 in Appendix, which suggest that (apart from the employment status) the observed differences regarding personal, 
household and contextual characteristics between the sample of emigrants with missing data on remittances and those with reported zero remittances are not statistically significant.

Table 4: The Explanatory Variables in the Estimations for the Incidence and Size of Remittances

\begin{tabular}{l|l}
\hline Explanatory variables & Definition of variables \\
\hline Personal characteristics & \\
\hline Age & Age of the emigrant \\
\hline Gender & Dummy=1 if male, 0 if female \\
\hdashline Education & $\begin{array}{l}\text { Dummies: less than upper-secondary (the omitted category), } \\
\text { upper-secondary and higher education }\end{array}$ \\
\hline Marital status & Dummy=1 if married, 0 otherwise \\
\hline Employment status & Dummy=1 if employed, 0 otherwise \\
\hline Household characteristics & \\
\hline Residence of the household & Dummy=1 if from urban areas, 0 if from rural areas \\
\hline Household size & Number of household members \\
\hline Household incomes per capita & $€ /$ month per capita without including remittances, in logs \\
\hline Contextual characteristics & \\
\hline Years as emigrant & Number of years since the first emigration \\
\hline Years as emigrant squared & Number of years since the first emigration squared \\
\hline
\end{tabular}

\section{Findings}

\section{Findings on the Probability of Remitting}

Estimates from the probit model are shown in Table 5. The Likelihood Ratio test strongly rejects the null hypothesis that all coefficients are jointly insignificant. The estimates suggest that males are more likely to remit compared to females, ceteris paribus. As expected, the coefficient on employment status is highly significant and positive, while that on household incomes is significant and negative. The estimates also suggest that the likelihood of remitting increases with years of emigration, but the coefficient is significant only at 10 percent. The quadratic term is insignificant and therefore does not support our expectations of the weakening household ties with years abroad (although the coefficient has the 
expected negative sign). We do not find a significant effect of education on the probability to remit and the coefficient even has a negative sign.

Table 5: Estimates from the Probit Model for the Determinants of the Probability of Remitting The Dependent Variable Equals 1 if the Emigrant Remits and 0 if Not

\begin{tabular}{|c|c|c|c|}
\hline Explanatory variables & Coef. & & $\mathbf{z}$ \\
\hline Constant & -2.989 & $* * *$ & -5.18 \\
\hline \multicolumn{4}{|l|}{ Personal characteristics } \\
\hline Age & 0.007 & & 0.64 \\
\hline Gender (male) & 0.924 & $* * *$ & 4.05 \\
\hline Upper-secondary education & 0.285 & & 1.27 \\
\hline Higher education & -0.166 & & -0.49 \\
\hline Married $\quad p_{n}$ & -0.160 & & -0.76 \\
\hline Employment status (employed) & 3.172 & $* * *$ & 9.42 \\
\hline \multicolumn{4}{|l|}{ Household characteristics } \\
\hline Household members & -0.025 & & -1.19 \\
\hline Household incomes per capita net of remittances ( $€ /$ month) & -0.434 & $* * *$ & -3.00 \\
\hline \multicolumn{4}{|l|}{ Contextual characteristics } \\
\hline Residence (urban) & -0.015 & & -0.08 \\
\hline Average years of emigration & 0.082 & * & 1.86 \\
\hline Average years of emigration squared & -0.002 & & -1.02 \\
\hline Log likelihood & -120.74 & & \\
\hline Likelihood Ratio test, $\chi_{(11)}^{2}$ & 380.78 & & \\
\hline Pseudo R-squared & 0.612 & & \\
\hline Mean dependent variable & 0.490 & & \\
\hline Observations & 449 & & \\
\hline
\end{tabular}

***, ${ }^{* *},{ }^{*}$ significant coefficient at 1,5 and 10 percent, respectively.

To quantify the effect of those explanatory variables that are significant on the probability of remitting, we proceed using the mean values of the explanatory variables, implying a representative person from our sample. This is just to give a sense of the size of the effect of the independent variables on the dependent one. Therefore, for a representative male who is 31 years old, with higher education, married, employed, from urban areas, from a household with 10 members, with household incomes per capita not including remittances at the sample average (€37 per month) and who has 8 years of emigration, the probability of remitting 
is 0.72 . For a similar female, this probability is 0.36 . Doubling the household incomes decreases the probability of remitting by 5 percentage points for males and by 4 percentage points for females. Increasing the years in emigration by one year, ceteris paribus, increases the probability of remitting by 1 percentage point for males and by 2 percentage points for females.

\section{Diagnostic Checks for the Tobit Model and Findings on the Amount Remitted}

We now comment on the findings from the Tobit model for the determinants of the size of remittances. Results are presented in column 1 of Table 6. Like in the probit model presented above, the Likelihood Ratio test rejected the null hypothesis that all of the estimated coefficients are jointly insignificant. Overall, the sign and the significance level of the coefficients are the same as in the probit model.

Before we discuss these findings, we examine if the Tobit model is appropriate to handle the corner solution due to $y=0$ for some of our observations. Note that in the Tobit model both the decision to remit and the magnitude of the amount remitted are explained by the same regressors and the direction of the effect of explanatory variables on $y_{i}$ is the same with regard to $P\left(y_{i}>0 \mid x_{i}\right)$ and $E\left(y_{i} \mid y_{i}>0, x_{i}\right)$. A simple specification check that is widely suggested to test the validity of this restriction is to compare the probit estimates from Table 5 (denoted by $\hat{\gamma}_{j}$ ) with the ratio of the Tobit coefficients from Table 6 to the standard error of the Tobit regression (denoted by $\hat{\beta}_{j} / \hat{\sigma}$ ) (Wooldridge, 2002, pp. 534-535; Greene, 2003, p. 776; Heij et al. 2004, p. 496).

If $\hat{\gamma}_{j}$ and $\hat{\beta}_{j} / \hat{\sigma}$ are largely different, it indicates that the decision whether to remit or not (that is $\left.\operatorname{Pr}\left(y_{i}>0\right)\right)$ may be driven by other factors than those factors determining the amount remitted given that $y_{i}>0$ (i.e. $E\left(y_{i} \mid y_{i}>0\right.$ ). Although, $\hat{\gamma}_{j}$ and $\hat{\beta}_{j} / \hat{\sigma}$ will never be identical, they should not be statistically different. For example, if $\hat{\gamma}_{j}$ is positive and significant but $\hat{\beta}_{j}$ is negative and perhaps 
insignificant, the Tobit model is probably misspecified. Or if $\hat{\gamma}_{j}$ and $\hat{\beta}_{j}$ are of the same sign, but $\hat{\beta}_{j} / \hat{\sigma}$ is much larger or smaller than $\hat{\gamma}_{j}$, then this could also indicate problems. One should not worry too much about sign changes or magnitude differences on the coefficients that are insignificant in both models.

Table 6: Estimates from the Tobit Model for the Determinants of the Size of Remittances The Dependent Variable is a Continuous Variable for the Emigrants that Remit ( $€$ ) month per emigrant, in log form), but Truncated to Zero for Those Emigrants That do Not Remit

\begin{tabular}{|c|c|c|c|c|c|c|c|c|}
\hline \multirow{3}{*}{ Explanatory variables } & \multicolumn{3}{|c|}{ Tobit estimates } & \multirow{3}{*}{$\begin{array}{c}\hat{\beta}_{j} / \hat{\sigma} \\
{[2]}\end{array}$} & \multirow{2}{*}{\multicolumn{2}{|c|}{$\begin{array}{c}\text { Unconditional } \\
\text { marginal } \\
\text { effects: } \\
\partial \mathrm{E}(\mathrm{y}) / \partial \mathrm{x}_{\mathrm{i}}\end{array}$}} & \multirow{2}{*}{\multicolumn{2}{|c|}{$\begin{array}{c}\text { Marginal effects } \\
\text { conditional on } \\
\text { being uncensored: } \\
\partial \mathrm{E}(\mathrm{y} \mid \mathrm{y}>0) / \partial \mathrm{x}_{\mathrm{i}}\end{array}$}} \\
\hline & \multirow{2}{*}{$\begin{array}{c}\text { Coeff. } \\
{[1]} \\
\end{array}$} & & \multirow[t]{2}{*}{$\mathbf{t}$} & & & & & \\
\hline & & & & & {$[3]$} & & {$[4]$} & \\
\hline Constant & -3.312 & $* * *$ & -6.68 & -2.944 & -1.685 & $* * *$ & -1.219 & $* * *$ \\
\hline \multicolumn{9}{|l|}{ Personal characteristics } \\
\hline Age & 0.007 & & 0.71 & 0.006 & 0.003 & & 0.002 & \\
\hline Gender (male) & 0.945 & $* * *$ & 5.01 & 0.839 & 0.418 & $* * *$ & 0.317 & $* * *$ \\
\hline Upper-secondary education & 0.305 & $*$ & 1.81 & 0.271 & 0.151 & $*$ & 0.110 & $*$ \\
\hline Higher education & -0.081 & & -0.30 & -0.072 & -0.040 & & -0.029 & \\
\hline Married & -0.125 & & -0.77 & -0.111 & -0.064 & & -0.046 & \\
\hline $\begin{array}{l}\text { Employment status } \\
\text { (employed) }\end{array}$ & 3.982 & $* * *$ & 12.50 & 3.538 & 1.651 & $* * *$ & 1.385 & $* * *$ \\
\hline \multicolumn{9}{|l|}{ Household characteristics } \\
\hline Household members & -0.007 & & -0.48 & -0.007 & -0.004 & & -0.003 & \\
\hline $\begin{array}{l}\text { Household incomes per } \\
\text { capita net of remittances }(€ / \\
\text { month) }\end{array}$ & -0.269 & $* * *$ & -2.76 & -0.239 & -0.137 & $* * *$ & -0.099 & $* * *$ \\
\hline \multicolumn{9}{|l|}{ Contextual characteristics } \\
\hline Residence (urban) & -0.035 & & -0.24 & -0.031 & -0.018 & & -0.013 & \\
\hline Average years of emigration & 0.073 & $* *$ & 2.29 & 0.065 & 0.037 & $* *$ & 0.027 & $* * *$ \\
\hline $\begin{array}{l}\text { Average years of emigration } \\
\text { squared }\end{array}$ & -0.002 & & -1.41 & -0.001 & -0.001 & & -0.001 & \\
\hline $\operatorname{Sigma}(\hat{\sigma})$ & 1.125 & & $0.06 \#$ & & & & & \\
\hline Log likelihood & -406.62 & & & & & & & \\
\hline Likelihood Ratio test, $\chi_{(11)}^{2}$ & 507.89 & & & & & & & \\
\hline Pseudo R-squared & 0.3839 & & & & & & & \\
\hline Mean dependent variable & 1.164 & & & & & & & \\
\hline Observations & 449 & & & & & & & \\
\hline $\begin{array}{l}\text { Uncensored observations } \\
(y>0)\end{array}$ & 220 & & & & & & & \\
\hline Censored observations $(\mathrm{y}=0)$ & 229 & & & & & & & \\
\hline
\end{tabular}

***, **, * significant coefficient at 1,5 and 10 percent, respectively. 
Results regarding $\hat{\beta}_{j} / \hat{\sigma}$ are given in column 2 of Table 6 , where we find that $\hat{\beta}_{j} / \hat{\sigma}$ are close to $\hat{\gamma}_{j}$ from Table 5 , with the signs and the significance levels the same. Therefore, the Tobit model seems to be appropriate, as there is no indication that the factors that determine the decision whether or not to remit would be any different from the factors that determine the amount remitted.

The interpretation of the Tobit estimates is difficult, because they do not measure directly the effect of interest but only the direction of this effect. The change in $y$ due to a change in $x_{i}$ is quantified by the unconditional and conditional marginal effects (presented in columns 3 and 4 of Table 6, respectively), which are based on Equations (8) and (9), respectively. The unconditional marginal effect should be larger than the conditional one, because it accounts both for changes in the conditional expectation of remittances where remittances are positive and for changes in the probability of remitting (Greene, 2003, pp. 764-66; Wooldridge, 2002, pp. 521-24; Wooldridge, 2006, pp. 597-600).

We now comment on those coefficients that are significant. For all emigrants, males remit 42 percent more than females (column 3), while of those who remit, males remit 32 percent more than females (column 4). Those who are employed remit 165 percent more than those who are not employed. Of the emigrants who remit, the employed remit 138 percent more than those who are not employed. Regarding household incomes, since both the dependent variable and household incomes are in logarithms, the estimated coefficient can be interpreted as elasticity. For all emigrants, a 1 percent increase in household incomes is associated with a decrease in remittances by 0.137 percent, ceteris paribus. Regarding emigrants who remit, as household incomes increase by 1 percent, the amount remitted decreases by 0.099 percent (or a 10 percent increase in household incomes decreases the amount remitted by 1 percent). Finally, for all emigrants an additional year of emigration increases remittances by 3.7 percent, while for emigrants who remit the amount remitted increases by 2.7 percent. 
Our findings are largely in line with those found elsewhere, although such evidence is very limited. Funkhouser (1995) also finds for El Salvador and Nicaragua that emigrants who are working are more likely to remit. When they do remit, then they remit more than migrants who are not working. Gender and age are found to be insignificant. Higher education is negatively correlated with the probability to remit, but of those who remit the more educated remit more. Note that, based on our discussion regarding diagnostic checks for the Tobit model, this finding may be taken as evidence of the model misspecification in Funkhouser's (1995) study. Funkhouser also finds that emigrants who left a spouse back home are more likely to remit and to remit more than other migrants who remit. Konica and Filer (2005) find for Albania that remittances are positively related to the employment status of the emigrant, the presence of the spouse in Albania and the emigrant's legal status.

To sum up, our data on remittances, especially with regard to their size, are imperfect for the reasons discussed above. Having in mind these limitations, our estimates suggest that males and employed emigrants are more likely to remit than their respective counterparts, ceteris paribus. In addition, out of those who remit, males and the employed remit more. The incidence of remitting and the size remitted decrease with the household income in Kosovo and increase with years of emigration.

\section{Conclusion}

In this paper, we have provided evidence on remittances in Kosovo that is important in several aspects. This issue has not been explored in such depth before and our analysis sets the stage for future research. Our literature review also found that such evidence for transition economies is very limited, therefore this analysis adds to the knowledge regarding remittances in transition economies.

The available data suggest that, compared to other transition economies, Kosovo ranks highly, both with regard to the rate of emigration of the labor force and 
the level of remittances to GDP. Remittances that these emigrants send home are the second largest source of household incomes (after labor incomes). Our econometric findings are largely consistent with the theory of migration in that the estimates on the determinants of the incidence and the size of remittances indicate that emigrants who are employed are more likely to remit than nonemployed emigrants. Among those emigrants who remit, employed emigrants remit more than the non-employed. The incidence of remitting and the amount remitted decrease with the household income in Kosovo and increase with years of emigration. These findings can be used to provide a better estimation (and forecast) of remittances. This may contribute to better estimation of consumption and savings by households and therefore improve the national accounts estimates in Kosovo.

Concerning the brain drain effect of emigration, the estimates suggest that around 11,000 of individuals with higher education are abroad, which is equivalent to four years output from higher education in Kosovo. This is in line with findings from other developing countries, but note that our estimates do not include permanent emigrants and therefore underestimate the brain drain in Kosovo. There are social costs and social benefits from the emigration of the work force, especially from the emigration of highly-skilled workers. The social costs consist of the public spending on their education and the absence of positive externalities to the society from a larger educated work force. It is difficult to conclude whether their remittances outweigh these costs. However, given poor employment prospects in Kosovo, temporary emigration remains a necessary short-term strategy for reducing unemployment. Now that the political situation is stable and the post-war economic reconstruction is almost over, there is the possibility that emigration and therefore remittances might decline. 


\section{Appendix}

Table A1: The Characteristics of the Sample used in Estimations of the Incidence and the Size of Remittances (emigrants of age 16+, all data is in proportion unless otherwise is stated)

\begin{tabular}{|c|c|c|c|}
\hline \multirow[t]{2}{*}{ Variables } & $\begin{array}{c}\text { All emigrants } \\
\text { (age 16+) }\end{array}$ & $\begin{array}{l}\text { Emigrants } \\
\text { who remit }\end{array}$ & $\begin{array}{l}\text { Emigrants that } \\
\text { do not remit }\end{array}$ \\
\hline & {$[1]$} & {$[2]$} & {$[3]$} \\
\hline Observations & 449 & 220 & 229 \\
\hline Incidence of remittances & 0.490 & 1.000 & 0.000 \\
\hline Amount remitted, $€ /$ month & 170.25 & 347.46 & 0.00 \\
\hline \multicolumn{4}{|l|}{ Personal characteristics } \\
\hline Age (average years) & 31.73 & 32.23 & 31.25 \\
\hline Gender (males) & 0.704 & 0.855 & 0.559 \\
\hline Education: less than upper-secondary & 0.283 & 0.232 & 0.332 \\
\hline Education: upper-secondary education & 0.615 & 0.682 & 0.550 \\
\hline Education: higher & 0.102 & 0.086 & 0.118 \\
\hline Married & 0.615 & 0.609 & 0.620 \\
\hline Employment status (employed) & 0.599 & 0.991 & 0.223 \\
\hline \multicolumn{4}{|l|}{ Household characteristics } \\
\hline Household members (number on average) & 9.815 & 9.286 & 10.323 \\
\hline Household income per capita $(€ /$ month) * & 37.82 & 37.64 & 37.99 \\
\hline \multicolumn{4}{|l|}{ Contextual characteristics } \\
\hline Residence (urban) & 0.359 & 0.391 & 0.328 \\
\hline Average years in emigration & 7.60 & 9.56 & 5.71 \\
\hline
\end{tabular}

Source of data: Riinvest HLFS of December 2002; *Without including remittances, 
Table A2: The Characteristics of the Sample of Emigrants with Missing Answers and with Reported Zero Remittances (emigrants of age 16+, data is in proportion unless otherwise is stated)

\begin{tabular}{|c|c|c|c|c|}
\hline \multirow[b]{2}{*}{ Variables } & All & $\begin{array}{c}\text { With } \\
\text { reported zero } \\
\text { remittances } \\
\left(\mu_{1}\right)\end{array}$ & $\begin{array}{c}\text { With missing } \\
\text { data on } \\
\text { remittances } \\
\left(\mu_{2}\right)\end{array}$ & $\begin{array}{l}\text { Test results: } \\
\mathrm{H}_{0}: \mu_{1}=\mu_{2}{ }^{*}\end{array}$ \\
\hline & [1] & {$[2]$} & {$[3]$} & [4] \\
\hline $\begin{array}{l}\text { Observations (all emigrants that do } \\
\text { not remit) }\end{array}$ & 229 & 34 & 194 & - \\
\hline $\begin{array}{l}\text { With reported zero amount of } \\
\text { remittance }\end{array}$ & 0.153 & 1.00 & - & - \\
\hline With missing data on remittances & 0.847 & - & 1.00 & - \\
\hline \multicolumn{5}{|l|}{ Personal characteristics } \\
\hline Age (average years) & 31.25 & 29.83 & 31.51 & Not rejected \\
\hline Gender (males) & 0.559 & 0.686 & 0.536 & Not rejected \\
\hline Education: less than upper-secondary & 0.332 & 0.229 & 0.340 & Not rejected \\
\hline Education: upper-secondary education & 0.550 & 0.629 & 0.536 & Not rejected \\
\hline Education: higher & 0.118 & 0.143 & 0.113 & Not rejected \\
\hline Average years of education & 10.94 & 11.54 & 10.83 & Not rejected \\
\hline Married & 0.620 & 11.34 & 18.38 & Not rejected \\
\hline Employment status (employed) & 0.223 & 1.000 & 0.082 & Rejected \\
\hline \multicolumn{5}{|l|}{ Household characteristics } \\
\hline Household members (average) & 10.32 & 9.71 & 10.43 & Not rejected \\
\hline $\begin{array}{l}\text { Household incomes per capita (€/ } \\
\text { month)* }\end{array}$ & 37.99 & 38.66 & 37.87 & Not rejected \\
\hline \multicolumn{5}{|l|}{ Contextual characteristics } \\
\hline Residence (urban) & 0.328 & 0.400 & 0.314 & Not rejected \\
\hline Average years in emigration & 5.71 & 6.00 & 5.65 & Not rejected \\
\hline
\end{tabular}

Source of data: Riinvest HLFS of December 2002; ${ }^{*} \mathrm{H}_{0}: \mu_{1}=\mu_{1}$ is rejected at 5 percent level of significance; ${ }^{* *}$ Without including remittances, 


\section{References}

Adams, Richard, 2003, "International Migration, Remittances and the Brain Drain: A Study of 24 Labor-Exporting Countries", World Bank Policy Research, No. 3069, Washington, D.C.: The World Bank.

Adams, Richard, 2005, "Remittances, Household Expenditure and Investment in Guatemala", World Bank Policy Research, No. 3532, Washington, D.C.: The World Bank. http://dx.doi.org/10.1596/1813-9450-3532

Amuedo-Dorantes, Catalina and Susan Pozo, 2006, "Migration, Remittances, and Male and Female Employment Patterns", American Economic Review, 96(2), pp. 222-226. http://dx.doi.org/10.1257/000282806777211946

Basker, Emek, 2003, "Education, Job Search and Migration", University of Missouri, unpublished paper, April.

Bauer, Thomas and Klaus Zimmermann, 1999, "Assessment of Possible Migration Pressure and Its Labour Market Impact Following EU Enlargement to Central and Eastern Europe", IZA Research Papers, No. 3, Bonn: Institute for the Study of Labor.

Bouhga-Hagbe, Jacques, 2006, "Altruism and Workers' Remittances: Evidence from Selected Countries in the Middle East and Central Asia", IMF Working Paper, No. 130, Washington, D.C.: International Monetary Fund.

Bush, Neil, 2004, "Review of Workers' Remittances to Kosovo", The World Bank, unpublished paper, February.

Catrinescu, Natalia, Miguel Leon-Ledesma, Matloob Piracha and Bryce Quillin, 2006, "Remittances, Institutions and Economic Growth", IZA Research Papers, No. 2239, Bonn: Institute for the Study of Labor.

Docquier, Frédéric and Hillel Rapoport, 2004, "Skilled Migration: The Perspective of Developing Countries”, World Bank Policy Research, No. 3382, Washington, D.C.: The World Bank. http://dx.doi.org/10.1596/1813-9450-3382 
Docquier, Frédéric, Olivier Lohest and Abdeslam Marfouk, 2005, "Brain Drain in Developing Regions 1990-2000”, IZA Research Papers, No. 1668, Bonn: Institute for the Study of Labor.

Fidrmuc, Jan, 2004, "Migration and Adjustment to Shocks in Transition Economies”, Journal of Comparative Economics, 32(2), pp. 197-373. http://dx.doi. org/10.1016/j.jce.2004.02.002

Funkhouser, Edward, 1992, "Migration from Nicaragua: Some Recent Evidence”, World Development, 20(8), pp. 1209-1218. http://dx.doi.org/10.1016/0305750X(92)90011-J

Funkhouser, Edward, 1995, "Remittances from International Migration: A Comparison of El Salvador and Nicaragua", Review of Economics and Statistics, 77(1), pp. 137-46. http://dx.doi.org/10.2307/2109999

Gedeshi, Ilir, 2006, "From Brain Drain to Brain Gain: Mobilising Albania's Skilled Diaspora", paper presented at the conference "Strengthening Research Capacities to Enhance the Benefits of Migration for Development”, Stockholm, June 2, 2006.

Greene, William, 2003, Econometric Analysis, 5th edition, New Jersey, NJ: Prentice Hall International.

Hanson, Gordon and Christopher Woodruff, 2003, "Emigration and Educational Attainment in Mexico", National Bureau of Economic Research, unpublished paper, April.

Heij, Christiaan, Paul de Boer, Philip Hans Franses, Teun Kloek and Herman K. van Dijk, 2004, Econometric Methods with Applications in Business and Economics, Oxford: Oxford University Press.

Konica, Nevila and Randall Filer, 2005, "Albanian Emigration: Causes and Consequences", paper presented at the conference "Third IZA Annual Migration Meeting” organised by IZA, Bonn, May 20, 2006. 
León-Ledesma, Miguel and Matloob Piracha, 2004, "International Migration and the Role of Remittances in Eastern Europe", International Migration, 42(4), pp. 65-82. http://dx.doi.org/10.1111/j.0020-7985.2004.00295.x

Mansoor, Ali and Bryce Quillin, 2007, Migration and Remittances: Eastern Europe and the Former Soviet Union, Washington, D.C.: The International Bank for Reconstruction and Development/The World Bank.

Moalla-Fetini, Rakia, Heikki Hatanpää, Shehadah Hussein and Natalia Koliadina, 2005, Kosovo: Gearing Policies toward Growth and Development, Washington, D.C.: International Monetary Fund.

Ratha, Dilip, 2004, Understanding the Importance of Remittances, Washington D.C.: The World Bank.

Rodriguez, R. Edgard and Erwin R. Tiongson, 2001, "Temporary Migration Overseas and Household Labor Supply: Evidence from Urban Philippines", International Migration Review, 35(3), pp. 709-725. http://dx.doi. org/10.1111/j.1747-7379.2001.tb00037.x

Salt, John, 2005, "Current Trends in International Migration in Europe", Council of Europe, No. CDMG(2005) 2, Strasbourg: Council of Europe.

Schiff, Maurice, 2005, "Brain Gain: Claims about Its Size and Impact on Welfare and Growth are Greatly Exaggerated”, IZA Research Papers, No. 1599, Bonn: Institute for the Study of Labor.

Schiopu, Ioana and Nikolaus Siegfried, 2006, "Determinants of Workers' Remittances: Evidence from the European Neighbouring Region”, European Central Bank, Working Paper Series, No. 688, Frankfurt: European Central Bank.

Schrooten, Mechthild, 2005, "Bringing Home the Money: What Determines Workers' Remittances to Former Socialist Countries", The Institute of Economic Research at Hitotsubashi University discussion paper, No. 446, Tokyo: The Institute of Economic Research at Hitotsubashi University. 
Stark, Oded, 2004, "Rethinking the Brain Drain”, World Development Report, 32(1), pp. 15-22. http://dx.doi.org/10.1016/j.worlddev.2003.06.013

Stark, Oded, Christian Helmenstein and Alexia Prskawetz, 1998, "Human Capital Depletion, Human Capital Formation, and Migration: A Blessing or a 'Curse'?", Economics Letters, 60(3), pp. 363-367. http://dx.doi.org/10.1016/ S0165-1765(98)00125-6

Tobin, James, 1958, "Estimation of Relationships for Limited Dependent Variables", Econometrica, 26(1), pp. 24-36. http://dx.doi.org/10.2307/1907382

Vidal, Jean-Pierre, 1998, "The Effect of Emigration on Human Capital Formation", Journal of Population Economics, 11(4), pp. 589-600. http://dx.doi. org/10.1007/s001480050086

Wooldridge, Jeffrey, 2002, Econometric Analysis of Cross Section and Panel Data, Cambridge, MA: MIT Press.

Wooldridge, Jeffrey, 2006, Introductory Econometrics: A Modern Approach, 3rd edition, Mason, OH: Thompson South-Western.

World Bank, 2006, Global Economic Prospects: Economic Implications of Remittances and Migration, Washington, D.C.: The World Bank.

Zimmermann, Klaus, 1995, European Migration: Push and Pull, Washington, D.C.: The World Bank. 